ELORE (ISSN 1456-3010), vol. 19 - 2/2012.

Julkaisija: Suomen Kansantietouden Tutkijain Seura ry.

[http://www.elore.fi/arkisto/2_12/enges.pdf]

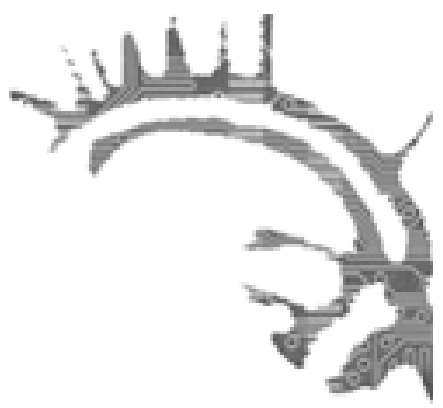

\title{
Ajankohtaista
}

\section{KANSANUSKONTUTKIMUS, PARADIGMAT JA KOULUKUNNAT}

\author{
Pasi Enges
}

Lectio praecursoria Turun yliopistossa 2.6.2012

Kun nuori Uno Holmberg (sittemmin Harva) aloitti opintonsa Helsingissä, Keisarillisessa Aleksanterin-yliopistossa vuonna 1908, hän hyvin nopeasti löysi omaksi erikoistumisalakseen suomalais-ugrilaisten kansojen uskonnot. Opettajikseen Holmberg sai kaksi tuon ajan merkittävää tutkijaa, Edward Westermarckin ja Kaarle Krohnin. Westermarck ohjasi oppilastaan uskontotieteelliseen ajatteluun ja ilmeisesti ainakin jossakin määrin myös etnografiseen kenttätyöhön, Krohn taas sai hänet kiinnostumaan suomalaisesta ja sukukansojen mytologiasta. Krohnin vaikutuksesta Holmberg myös sitoutui suomalaiseen kansanrunoudentutkimuksen menetelmään. (Anttonen 1987, 50-53.) Kaarle Krohnin ympärille oli syntynyt suomalaisena koulukuntana tunnettu tutkijayhteisö, jonka tutkimustyö nojautui Julius Krohnin kehittämään ja Kaarle Krohnin viimeistelemään maantieteellis-historialliseen menetelmään. Menetelmä perustui 1) lähdeaineiston yksityiskohtaiseen, kriittiseen tarkasteluun, 2) kehitysopilliseen näkemykseen, jonka mukaan jokaisella kulttuurin ilmiöllä on oma, itsenäinen kehityshistoriansa ja 3 ) maantieteelliseen lähestymistapaan, jossa tutkimusaineistossa havaitut erot ja yhtäläisyydet tuli suhteuttaa muistiinpanojen maantieteelliseen jakautumiseen. Tutkimusongelmat kohdistuivat perinteen kehityshistoriaan sekä syntypaikkojen ja alkuperäisten muotojen selvittämiseen. (Esim. Hautala 1954, 190-192, 241-246; Kuusi 1980, 25-30.)

Uno Holmberg sai Kaarle Krohnilta pro gradu -tutkielmansa aiheeksi "Lapin uskon- 
Pasi Enges: Kansanuskontutkimus, paradigmat ja koulukunnat

nonhistorian" ja vuonna 1910 valmistunut tutkielma ilmestyi viisi vuotta myöhemmin korjailtuna Suomen suvun uskonnot -sarjassa nimellä Lappalaisten uskonto. Tohtoriksi Uno Holmberg väitteli vuonna 1913 aiheenaan suomalais-ugrilaisten kansojen vedenjumaluudet. Molemmat työt ovat maantieteellis-historiallisen menetelmän periaatteiden ja aiemman tutkimuksen antamien mallien mukaisia. Väitöskirjan ilmeinen esikuva on sekä kysymyksenasettelun että käsittelytavan puolesta Julius Krohnin vuonna 1894 ilmestynyt Suomen suvun pakanallinen jumalanpalvelus. Holmbergin tutkimuksen keskeinen kysymys on, mitä ovat eri suomalaisugrilaisten kansojen alkuperäiset vedenhaltija- ja jumalolennot. Mikä on omaa ja alkuperäistä, mikä myöhemmän kehityksen tulosta, mikä vierasta lainaa? Käsittelyjärjestys on maantieteellis-historialliselle menetelmälle ominaisen kehitysopillisen ajattelun mukainen: aloitetaan primitiivisinä pidetyistä saamelaisista, hanteista ja manseista, ja päädytään kehittyneimpinä pidettyihin virolaisiin, suomalaisiin ja unkarilaisiin. Myös Lappalaisten uskonto mukaili sekä sisällöltään että rakenteeltaan Krohnin teosta. Esikuvallisena tutkimuksena Suomen suvun pakanallinen jumalanpalvelus osoitti, mitä asioita pitää käsitellä, kun kirjoitetaan yleisesitys jonkin kansan uskonnosta. (Hautala 1954, 300-302.)

Maantieteellis-historiallinen menetelmä perustui vahvaan teoriaan suullisen perinteen olemuksesta ja lainalaisuuksista. Samalla se oli myös käytännöllinen työohjelma, jota tunnollisesti noudattamalla oli mahdollista päästä tieteellisesti ansiokkaisiin lopputuloksiin. Kaarle Krohnin sanoin, se oli "yleensä kaikessa kansanrunoudentutkimuksessa ainoa oikea ja perille vievä tie”. Otin Uno Holmberg-Harvan tässä esiin yhtenä esimerkkinä tutkijasta, jonka ura käynnistyi vallalla olevan tutkimussuuntauksen suojissa ja joka aluksi omaksui ja pyrki noudattamaan tunnollisesti suuntauksen periaatteita. On tunnettua, että Harva myöhemmin erkani näistä lähtökohdistaan kehittäk̈kseen oman uskontoetnografisen tutkimustapansa.

\section{TUTKIMUKSEN PARADIGMAT}

Suomalaisen kansanuskontutkimuksen oppihistoriassa on eroteltavissa eri vaiheita, joissa jokin teoreettinen tai metodologinen suuntaus on saanut erityistä painoarvoa ja joissa tutkimuksen kohteet ja tutkimuksen tekemisen tavat ikään kuin luonnostaan näyttävät ottavan tietyn suunnan. Jos eivät ainoina mahdollisina, kuitenkin tärkeimpinä pidettyinä ja tavallaan itsestään selvinä tällaiset suuntaukset ohjaavat tieteenalalla tehtävää ajankohtaista tutkimusta. Vallalla olevia tutkimussuuntauksia, niitä tutkimuksen tekemisen tapoja, joita tieteenalalla toimiva tutkijayhteisö tai ainakin sen enemmistö pitää oikeina, on kutsuttu paradigmoiksi. Paradigmaa voidaan luonnehtia yleisesti hyväksytyksi tavaksi tehdä tieteellistä tutkimusta. Paradigmoille on kuitenkin tyypillistä, että niitä ei omana aikanaan useinkaan määritellä selkeästi ja lausuta ääneen, vaan ne tulevat näkyviksi vasta tilanteissa, joissa uusi paradigma on korvaamassa vanhan ja tutkimuksen tekemisen periaatteita ja pelisääntöjä aletaan kyseenalaistaa ja uudistaa. Tavallisesti vasta ajallinen perspektiivi ja oppihistoriallinen uteliaisuus tuottavat koherentin kuvauksen siitä, mikä oli omana aikanaan tutkijoille arkipäiväistä ja itsestään selvää. 
Pasi Enges: Kansanuskontutkimus, paradigmat ja koulukunnat

Anna-Leena Siikala on pohjoismaisen kansanuskontutkimuksen historiaa koskevassa kommenttiartikkelissaan (1983) esittänyt tiiviisti keskeiset teoreettiset tekijät, joiden kautta on mahdollista tarkastella tutkimuksen suuntautumista ja paradigmojen syntyä. Ensimmäinen näistä on tiedonintressi: mitä tarkoitusta varten kansanuskoa on eri aikoina merkitty muistiin ja tutkittu? Kuten oppihistorioitsijat ovat osoittaneet, on tutkimuksen käyttövoimana toisinaan ollut voimakkaitakin uskonnollisia, poliittisia ja nationalistisia vaikuttimia. Puhtaasti tieteellinen mielenkiinto aihepiiriin on suhteellisen uusi ilmiö ja toisaalta täysin poliittisesti arvovapaan tutkimuksen mahdollisuus voidaan syystä kyseenalaistaa.

Toinen teoreettinen tekijä on tutkimuskohteen määrittely: mitä kansanusko pohjimmiltaan on ja miten se on määriteltävissä? Mikä on se kansa, jonka uskosta ollaan kiinnostuneita? Varhainen tutkimus aina 1800-luvun lopulle saakka etsi kansaa esikristillisestä menneisyydestä; haluttiin rekonstruoida suomalaisten alkuperäinen, kristinuskoa edeltänyt uskonto, suomalainen mytologia. Myöhemmin tutkijoille kansaa edusti 1800-luvun ja 1900-luvun alun maaseutuväestö. Ajatus siitä, että nykyaikaisella kaupunkilaisellakin voisi olla perinteitä ja kansanomaisia uskomuksia, antoi odottaa itseään aina 1960-luvulle saakka. Nykyaikainen käsitys on, että jokaisen ihmisen elämään liittyy piirteitä, joita voidaan pitää kansanuskona. Kysymys on siitä, miten usko määritellään. Tarkoitetaanko sillä ulkoisesti havaittavia, yhteisöllisiä tai yksilöllisiä käyttäytymisen muotoja, kuten rituaaleja tai sanallisia ilmauksia vai mielentiloja, asenteita ja kansanomaisen ajattelun muotoja?

Kolmantena tutkimusta määrittävänä tekijänä on tutkimustiedon ja tutkimusaineistojen karttuminen. Suomalaisen kansanuskontutkimuksen kenttä laajeni 1800-luvun mytologiakeskeisyydestä 1900-luvun alussa ennen kaikkea loitsu- ja taikaperinteen tutkimukseen. Kertomusperinne nousi tutkimuksen lähdeaineistoksi 1940-luvulta lähtien. Laajojen, maantieteellisesti kattavien lähestymistapojen rinnalle nousivat pienyhteisö- ja yksilötutkimus 1960-luvulta lähtien ja moderni, urbaani kansanusko ja parapsykologia tarjoutuivat luonnolliseksi jatkoksi maaseutuväestön kansanuskolle 1970-luvulla. Nykyaikana vaikkapa UFO-uskomukset tai monet niin sanotut uuspakanalliset liikkeet, kuten wicca tai vanhaa suomalaista kansanuskoa elvyttävä suomenuskoisuus, ovat esimerkkejä uusista tutkimuskohteista.

Tieteelliselle tutkimukselle on tyypillistä, että löydetyt vastaukset nostavat esiin uusia kysymyksiä. Tavallista on myös, että aikaisemman tutkimuksen tulokset eivät uuden paradigman vallitessa ole enää tyydyttäviä, vaan vaativat uudenlaista tutkimusta ja tulkintaa. Neljäntenä tutkimusta ohjaavana teoreettisena tekijänä ovat teoriat ja metodit, joiden avulla uutta tietoa tuotetaan. Kehittyessään tieteenala kehittää, lainaa ja muokkaa omiin tarpeisiinsa kulloinkin sopivia työkaluja. Maantieteellis-historiallinen menetelmä on paraatiesimerkki, mutta sen jälkeen on tullut ja mennyt monia: perinnepsykologia, perinnemaantiede, kartografia, funktionalismi, perinnelajiteoria, strukturalismi, narratologia jne. Uudet teoriat ja menetelmät johdattavat usein nykyaikaisenkin tutkijan palaamaan menneisyydessä jo tutkittujen aihepiirien ja aineistojen pariin.

Paradigman käsitteestä on vaikeata puhua nostamatta sen rinnalle koulukunnan käsitettä. Koulukunta muodostuu samoja tieteellisiä periaatteita noudattavien tutkijoiden joukosta, joskus hyvinkin läheisesti yhteistyötä tekevistä oppisuunnan edustajista. Kou- 
Pasi Enges: Kansanuskontutkimus, paradigmat ja koulukunnat

lukuntia nimetään esimerkiksi menetelmän, paikkakunnan tai johtohahmojen mukaan. Tavallisesti koulukunta vaatikin syntyäkseen vahvan johtajan, joka kykenee tuomaan tieteenalalle sellaisen uudistuksen, että tutkijayhteisö vakuuttuu tuon uudistuksen erinomaisuudesta ja välttämättömyydestä. Edellä mainittujen maantieteellis-historiallisen koulukunnan johtohahmojen, Julius ja Kaarle Krohnin, jälkeiseltä ajalta voidaan puhua esimerkiksi haaviolaisesta koulukunnasta, johtohahmonaan Martti Haavio motiivihistoriallisine tutkimustapoineen. Maantieteellis-historiallisen koulukunnan jälkeen ehkä selkeimmin erottuva, uutta tieteellistä paradigmaa toteuttanut tutkijayhteisö syntyi kuitenkin 1960-luvulla Turun yliopistoon professori Lauri Hongon johdolla.

\section{TURUN KOULUKUNTA}

Pohjoismaisessa folkloristiikassa suurin ja vaikuttavin paradigman muutos osui 1950-60-lukujen taitteeseen. Kun aikaisemmin tutkimus oli keskittynyt perinneteksteihin (kuten runoihin, kertomuksiin, lauluihin) ja niiden alkuperää, historiaa ja levinneisyyttä koskeviin kysymyksiin, voimistui 1960-luvun alusta lähtien kulttuuri- ja sosiaaliantropologiasta vaikutteita saanut suuntaus. Uudessa lähestymistavassa painottui folkloren asema kulttuurisen viestinnän välineenä. Kiinnostuksen kohteiksi tuli se, miten perinne välittyy, miten sitä käytetään ja mikä on sen merkitys yhteisössä. Perinteen keruu ja sen tutkimus oli aikaisemmin erotettu selvästi toisistaan ja tutkijoiden tekemä työ perustui pääasiassa käsikirjoituksista koostuvaan arkistoainekseen. Uusi, niin sanottu antropologinen folkloristiikka taas painotti tutkimuksen ja kenttätyön elimellistä yhteyttä. Folklorea tuli tutkia tässä hetkessä erilaisissa yhteisöissä elävänä kulttuurina, ei historiallisena ilmiönä. Suuntausta tukivat sekä kenttätyöhön perustuvan tutkimuksen ja systemaattisten kenttätyömenetelmien kehitys että edistynyt dokumentointiteknologia.

Myös tutkimuksen kohteet monipuolistuivat. Aiempi tutkimus oli useimmiten ollut maantieteellisesti laaja-alaista ja perinteen ilmiöitä ikään kuin kaukaa katsovaa. Nyt katseet kohdistuivat pienyhteisöihin, ryhmiin ja yksilöihin. Tarvittiin lähikuvia, joissa tulisi näkyväksi suullisen perinteen elämä pienyhteisöissä ja yksilöiden elämässä. (Lehtipuro 1980, 8-9.)

Kun Turun yliopistoon perustettiin vuonna 1963 vertailevan kansanrunoudentutkimuksen ja uskontotieteen henkilökohtainen ylimääräinen professuuri ja seuraavana vuonna samanniminen laitos, oli kysymyksessä uusi ja ainutlaatuinen oppiaineiden yhdistelmä. Professoriksi nimitetty Lauri Honko oli vuonna 1962 julkaisut sittemmin klassikoksi muodostuneen inkeriläistä haltijauskoa koskevan tutkimuksensa Geisterglaube in Ingermanland. Tutkimuksessa hyödynnettiin vakuuttavasti sosiologian, sosiaali- ja havaintopsykologian ajankohtaisia tutkimustuloksia. Tutkimuskysymykset eivät kohdistuneet perinteen levinneisyyteen tai historiaan, vaan tarkastelun kohteena oli ajallisesti ja paikallisesti rajattu sosiaalinen miljöö (Inkerinmaa 1800-luvun lopulta toiseen maailmansotaan), jossa tunnettu ja käytetty haltijaperinne analysoitiin yksityiskohtaisesti. Honko asetti tutkimuksessaan seuraavanlaisia kysymyksiä: Minkälaisessa sosiaalisessa ympäristössä haltijausko oli elävää? Mikä oli haltijaelämysten psykologinen ja sosiaalinen 
perusta? Kuka näki tai kuuli haltijoita, millaisissa olosuhteissa ja miksi? Miten haltijausko ja haltijoiden todelliseksi koettu kohtaaminen vaikutti ihmisten käyttäytymiseen? Tämänkaltaisiin kysymyksenasetteluihin oli vanhemmassa tutkimuksissa vain joitakin haparoivia viittauksia, nyt ne olivat tutkimuksen keskipisteessä. Tutkimusmenetelmä oli ennen kaikkea funktioanalyyttinen (kysyttiin siis perinteen tehtäviä) ja perinnelajianalyyttinen (eroteltiin kansanuskoa kuvaavat suullisen perinteen lajit ei-uskonnollisista). (Honko 1962; ks. myös Lehtipuro 2008).

Geisterglaubea ja eräitä Hongon perinnelajianalyysia koskevia artikkeleja voidaan pitää "Turun koulukunnan" metodologisena kivijalkana. Unohtaa ei myöskään sovi Hongon lähimmän työtoverin Juha Pentikäisen monia tutkimusnäkökulmia soveltavaa ja erilaisia aineistotyyppejä hyödyntävää väitöskirjaa pohjoismaisesta lapsivainajaperinteestä ja hänen tutkimustaan Marina Takalon uskonto (Pentikäinen 1971), joka samoin useita erilaisia menetelmiä sekä folkloristiikan, uskontotieteen ja antropologian näkökulmia yhdistelemällä keskittyy yhden yksilön koko suulliseen repertoaariin ja siinä välittyvään maailmankuvaan.

Kun itse aloitin folkloristiikan opinnot Turun yliopistossa 1970-luvun lopulla, Turun koulukunnan henki vaikutti edelleen vahvana, vaikka en sitä silloin selvästi tiedostanutkaan. Ellen muista aivan väärin, meillä opiskelijoilla oli kuitenkin jonkinlainen yhteinen käsitys siitä, että folkloristiikka on Turussa jotakin olennaisesti erilaista kuin esimerkiksi Helsingin yliopistossa. Geisterglauben perusideat tulivat opinnoissa toistuvasti vastaan. Kansanusko oli suosittu aihepiiri opinnäytetöissä, joista monissa folkloristiikan ja uskontotieteen kysymyksenasettelut kietoutuivat luontevasti toisiinsa. Opiskelutoverieni tavoin minustakin tuli huomaamattani Turun koulukunnan oppilas ja seuraaja.

Saamelaisen folkloren tutkimusprojekti, joka käynnistyi Turun yliopistossa Lauri Hongon ja Juha Pentikäisen aloitteesta, oli yksi vastaus 1960-luvun antropologisen folkloristiikan tarjoamaan haasteeseen. Projekti käynnistyi laajana, Suomen, Ruotsin ja Norjan Lappiin ulottuvana saamelaisperinteen yleiskeruuna, mutta täsmentyi nopeasti Teno-joen varressa sijaitsevaan Talvadaksen jokisaamelaiskylään ja sen naapurikyliin. (Nyberg, Huuskonen \& Enges 2000.) Tavoitteena oli kylän suullisen perinteen mahdollisimman kattava dokumentointi. Yli neljän vuosikymmenen ajan karttunut materiaali on suurimmaksi osaksi vielä analysoimatta. Oma tutkimukseni pohjautuu tähän aineistoon ja käyttämäni haastattelut ulottuvat aivan projektin alkuvaiheesta, vuodesta 1967, 2000-luvun alkuvuosina itse tekemiini.

Kansanuskontutkimuksen kannalta suullisen perinteen lajeista keskeisimmäksi Turun koulukunnan piirissä osoittautui memoraatti. Memoraatilla tarkoitetaan kertomusta kertojan itsensä tai hänen tuntemansa henkilön yliluonnollisesta elämyksestä. Niin Geisterglaubessa kuin muissakin edellä mainituissa tutkimuksissa memoraatit olivat keskeinen lähderyhmä. Lauri Honko korosti memoraattien ensisijaisuutta kansanuskon tutkimuksessa, koska niistä kaikkein selvimmin käyvät ilmi tilanteet, joissa yliluonnollista on koettu. Kertomuksena memoraatti on lähimpänä alkuperäistä elämystä. (Honko 1964)

Omilta opiskeluajoiltani muistan, miten memoraatti-lajitermillä oli aivan erityinen kaiku. Se merkitsi enemmän kuin sisällöllisesti jännittävää kertomusta; sen takana oli ihmetystä herättävä, usein pelottavakin tapaus, jonka joku oli todella kokenut. Aidon memoraatin kuulemista ja talteen saamista haastattelutilanteessa pidettiin suuressa arvossa. 
Ei siis ihme, että oma kiinnostukseni kohdistui juuri tähän kertomuslajiin. Saamelaisen folkloren tutkimusprojektin aineistoon oli kertynyt suuri määrä memoraattimuotoisia kertomuksia juuri siksi, että Lapissa liikkuneet kenttätutkijat olivat haastatteluissaan aktiivisesti pyrkineet jäljittämään niitä. Talvadaksen kylän Rasmus-suvun jäseniltä taltioitu runsas memoraattimateriaali osoittautui sopivaksi aineistoksi väitöstutkimukselleni.

Tutkimukseni lähtökohdat palautuvat suoraan Turun koulukuntaan ja sen tapaan yhdistää folkloristisia ja uskontotieteellisiä kysymyksenasetteluja perinnelajianalyyttisiin, funktionalistisiin ja yliluonnollisia elämyksiä selittäviin psykologisiin analyysi- ja tulkintamalleihin. Toisaalta olen tutkimuksessani nojautunut kerronnantutkimuksen lähestymistapoihin, jotka Turun koulukunnan huippuvuosina olivat vasta tulollaan. Tutkimusprosessini aikana jouduin kysymään, minkälainen laji memoraatti itse asiassa on, mitä sillä voidaan tehdä ja minkälaista kansanuskoa se ilmentää. Tulin huomaamaan, että kaikki totena kerrotut kertomukset eivät kuvaakaan todellisia yliluonnollisia elämyksiä. Kertomuksia voidaan keksiä tai todella tapahtuneesta voidaan puhua liioitellen ja uskottavuuden rajoja koetellen. Lapinlisä on kertojien itsensäkin käyttämä ilmaus, jolla tarkoitetaan tällaista kertomusten maustamista mielikuvituksellisilla aineksilla.

Ymmärsin myös, että yliluonnollisen todistaminen todella olemassa olevaksi on vain yksi - eikä välttämättä tärkein - memoraattien kertomisen tehtävä. Samoilla kertomuksilla voidaan myös viihdyttää, huvittaa, osoittaa kertojantaitoja, kyseenalaistaa, pilailla kuulijan kustannuksella, välittää sosiaalisia normeja, opettaa jne. Uskominen osoittautui yksilö- ja tilannekohtaisesti suuresti vaihtelevaksi asennoitumiseksi yliluonnollisiin olentoihin ja ilmiöihin. Yleistävä "saamelaiset uskovat" -tulkinta sai tutkimuksessani väistyä monivivahteisemman, perinteen eri käyttö- ja tulkintatavat huomioon ottavan näkemyksen tieltä. Tärkeäksi osoittautui myös kahden läheisen ja toisinaan synonyymeinakin käytetyn käsitteen, kansanuskon ja uskomusperinteen, erillään pitäminen. Kansanusko määrittyy työssäni ihmisen suhteeksi yliluonnollisiksi ymmärrettyihin olentoihin ja voimiin. Uskomusperinteellä taas tarkoitan folkloren ja tapakulttuurin lajeja, joiden kautta kansanuskon elementit välittyvät yhteisön sisällä ja sukupolvelta toiselle.

Kansanuskolla on ollut keskeinen asema suomalaisen folkloristiikan tutkimushistoriassa. Nykypäivänä tutkimusintressit kuitenkin ovat enimmäkseen muualla ja kansanuskon aiheiden parissa ahkeroivat tutkijat ovat laskettavissa, jos eivät yhden, niin ainakin kahden käden sormin. Oman panokseni nykypäivän kansauskontutkimukseen yleensä ja saamelaisen uskomusperinteen tutkimukseen erityisesti näen kahdenlaisena. Ensiksikin katson jatkavani jo opiskeluaikana omaksumiani Turun koulukunnan perinteitä: myös minun kysymyksenasetteluni ovat peruslaadultaan perinnelajianalyyttisia ja funktionalistisia. Toisaalta olen päivittänyt tutkimusta tuomalla näihin kysymyksenasetteluihin mukaan uusia näkökulmia, näistä tärkeimpänä kerronnan analyysi nimenomaan yliluonnolliseen asennoitumisen kannalta.

Käsittelen tutkimuksessani Saamelaisen folkloren tutkimusprojektin aineistoa tavalla, joka ei ollut - eikä voinutkaan olla - projektin aloittaneiden tutkijoiden näköpiirissä. En usko meneväni pahasti harhaan, kun ennustan, että väitöskirjani on viimeinen suoraan Turun koulukunnan oppeihin ja Lauri Hongon perintöön palautuva tutkimus. 
Pasi Enges: Kansanuskontutkimus, paradigmat ja koulukunnat

ENGES, PASI 2012: "Minä melkein uskon". Yliluonnollinen ja sen kohtaaminen tenonsaamelaisessa uskomusperinteessä. Turku: Turun yliopisto.

\section{KirJallisuUs:}

ANTTONEN, VEIKKO 1987: Uno Harva ja suomalainen uskontotiede. Suomi 138. Helsinki: SKS.

HAUTALA, JOUKO 1954: Suomalainen kansanrunoudentutkimus. Helsinki: SKS.

HONKO, LAURI 1962: Geisterglaube in Ingermanland. Folklore Fellows Communications 186. Helsinki: Suomalainen Tiedeakatemia.

HONKO, LAURI 1964: Memorates and the Study of Folk belief - Journal of the Folklore Institute $1(1 / 2)$.

KUUSI, MATTI 1980: Suomalainen tutkimusmenetelmä. - Lehtipuro, Outi (toim.), Perinteentutkimuksen perusteita. Porvoo - Helsinki - Juva: WSOY.

LEHTIPURO, OUTI 1980: Perinteentutkimus tienhaarassa. - Outi Lehtipuro (toim.), Perinteentutkimuksen perusteita. Porvoo - Helsinki - Juva: WSOY.

LEHTIPURO, OUTI 2008: Unohdettu klassikko? - Inkerin haltijauskon tutkimus ja suomalaisen folkloristiikan käänne. - Sananjalka 50.

NYBERG, PATRICIA \& HUUSKONEN, MARJUT \& ENGES, PASI 2000: Observations on Interview in a Depth Study on Saami Folklore. - Lauri Honko (ed.), Thick Corpus, Organic Variation and Textuality in Oral Tradition. Studia Fennica Folkloristica 7. Helsinki: Finnish Literature Society.

PENTIKÄINEN, JUHA 1971: Marina Takalon uskonto. Uskontoantropologinen tutkimus. Helsinki: SKS.

SIIKALA, ANNA-LEENA 1983: Commentary. - Lauri Honko \& Pekka Laaksonen (eds.), Trends in Nordic Tradition Research. Studia Fennica 27. Helsinki: SKS.

Filosofian tohtori Pasi Enges on folkloristiikan yliopisto-opettaja Turun yliopistossa. 